\title{
SECURITY SECTOR REFORMS IN THE REPUBLIC OF MACEDONIA: NEED FOR TRANSFORMATION
}

\author{
Oliver Bakreski \\ Faculty of Philosophy, Institute of Security, Defense and Peace - Skopje
}

\begin{abstract}
The security sector reform is a broadly accepted concept that refers to the improvement of the working methods and functioning of the security sector. Respectively, it also includes a wide platform for realization and concretization of certain tasks directed towards improvement of the internal structure of the security sector. These tasks arise from the new developments and hence they focus mainly on such an appropriate transformation of the security structures, which would not bring to danger the real capabilities for enforcing the security policies. The theoretical focus of this paper is primarily on review of the reform challenges to the security sector. Secondly, the paper recognizes the great significance of transparency and accountability promotion, as these are basic principles for democratic functioning of any security sector in a democratic society.
\end{abstract}

Key words: reforms, security, security sector, defense sector, transformation.

\section{Introduction}

The security sector reform represents both a political and an empirical concept. The fundamental goal of the reforms in this sector should be directed towards the build-up of armed forces and the other security forces that would be at the same time effective and efficient; on the other hand, this concept refers also to the state institutions and capacities that would carry out regular democratic oversight and management of the entire security sector. Continuity and success of the reforms in the security sector depend on the solid social and economic programs. In other words, in long run the necessary reforms in the security sector are possible only if accompanied by adequate socio-economic reforms. Hence, the security sector reform remains a significant subject of interest especially in post-authoritarian and post-conflict societies. One could even say that sustainable peace and development depend on the success of the security sector reform. 
The national program that sustains security sector reform in the Republic of Macedonia is supposed to enable transformation of the security and political structures in a manner that would not sacrifice transparency and democratic accountability for the sake of efficiency. Security sector reform entails a wide range of activities, such as:

1. Establishment of an adequate political framework that would allow development of the security sector reform and any additional legitimation that would ensure public support;

2. Personnel training for the issues that arise from the reforms.

3. Capacity building and human resources for the security sector reform.

4. Set up of functional structures.

5. Development of tools necessary for implementation the security sector reforms and accompanying policies.

6. Development of various forms of cooperation with all interested parties (the UN, NATO, EU, civil society and other international partners and donors).

\section{General Framework of Security Sector Reform}

The security sector reforms are a relatively new concept, which replaces the former, less comprehensive programs such as force reduction, defense reforms and adaptations for the sake of national security of a single state. Its goal is enabling sufficient services in the security sphere that would respond successfully to the new security threats but would also be adjusted to the state's financial capacities. However, few countries in the world are capable of maintaining an independent security sector; most of them reply to some degree on the increased international cooperation as a supplement for the national inter-agency teamwork (Fluri and Shalamanov 2003, p. 242; Bruden and Hänggi 2004, pp. 5-6; Bakreski 2008). The modern security sector's structure is rather comprehensive: in addition to the traditional security structures (military and police), it also embraces all other state bodies and institutions that are entitled to carry and use weapons i.e. employ coercive force, such as: border guards, intelligence services, financial police, special anti-terrorist units, customs, judicial and penitentiary guards. In addition, one should include the structures which are result of privatization of security (Damian, Lilly D. and Page T. 2002; Bakreski 2008). Despite the wide acceptance of the notion of the security sector reform, there are still theoretical dilemmas over the meaning of the phrase "reform" and its essence. In general, 
the reform achievements are most often the final result of a long process of reform. The quality of the results is directly dependent on the way the reform process itself has been carried out. Complexity is main characteristic of any state-related process but this one bears special significance because it may be crucial for the complete transformation of a country. However, in addition to the benefits the process may imply big financial costs for the state budget. In such a case, the success of the security sector reform depends on the political leadership's determination to consistently administer the reforms regardless the political costs they may induce.

The goal of the security sector reform is enable functioning of an efficient security system that would embrace adequate security capabilities as a response to the potential threats. The security sector reforms contribute not only to the better readiness and efficiency of the security apparatus but it also strives to make the security structures more responsible for their missions and accountable to the public at the same time. Therefore each phase of the reforms calls for serious approach and attitude; by default each phase should be based on an intelligent, well-grounded and coherent presentation of the progress achieved in any of the priority spheres.

The overall purpose of the "security sector reform" is not only establishment of such security institutions that would be efficient but also that would be legitimate and democratically responsible in their mission of providing external and internal security to the citizens. The security sector reform demands numerous consultations with various stakeholders and it assumes a range of goals, such as: strengthening civilian control and oversight of the security sector; professionalization of the security forces; demilitarization and peace-building and rule of law. The key principles for any activity related to the security sector reform are: good governance, efficient security definition and respect for human rights and international humanitarian law (Clingendael 2002).

Basically, the security sector reform is and will remain politically sensitive area which demands full engagement of all state subjects and not only the ones that are professionally a part of the security system. It means that there is a need for a transparent reform plan, based on the official political documents enacted in the parliament, implemented through a package of governmental programs (supported by the budget means or foreign assistance). For the plan to be legitimate and supported by the general public it is necessary to establish close cooperation of the politicians, the administration, civil society and business community (Shalamanov 2003). 


\section{Securiaty}

\section{Security Sector Reform in the Republic of Macedonia}

Security sector reform in the Republic of Macedonia has been an ongoing process for quite some time. There are numerous rationales (both external and internal) for the reforms in the security sphere. The subjects involved in the reforms have various interests, motives and potentials to enforce them. This fact influences the result of the reform. Some of the motivations and interests are public; others are hidden, and could be identified and assessed only indirectly through analysis of the activities undertaken by some subjects (Slaveski 2009).

The external causes for the security sector reforms in the Republic of Macedonia include the following: the change of the security environment since the dissolution of the Warsaw Pact, the Soviet Union and Yugoslav Federation; the Republic of Macedonia's goal to gain NATO and EU membership is determined by successful reform of the security system; new security risks for the national security (such as terrorism, organized crime, intra-state upheaval, etc.) (Slaveski 2009).

As internal factors that call for security sector reform one could list the following ones: completion of the restructuring process of the security system in order to make it operative and in accordance with the resources which are at disposal; transformation and designation of security structures according to the country's security needs; decrease the personnel in a number ratio which should enable structured, operative and technically equipped security system; de-politicization of the security sector; intensifying the preparations for dealing with the global terrorism, as a major threat that may demand additional capacities; recruitment of professionals according the required qualifications and specific competencies etc.

\section{Some aspects of the security sector reforms in the Republic of Macedonia}

Public and professional debate over security sector reform in the Republic of Macedonia has been opened relatively late. The issue became urgent only after the 2001 conflict in the context of implementation of the Ohrid Framework Agreement. It gained intensity after the 2002 NATO summit in Prague. One internal and one international event actually served as catalysts of the processes. Both the domestic and the international actors agreed that the issue for the security sector reform has to get necessary attention. However, not everything went without problems. It could be said that both involved parties in the process, the domestic and the international ones, had different, and sometimes even 
contradictory standpoints about what and how should something be reformed (Vankovska 2006).

There is a wide-spread opinion that every single reform endeavor in Macedonia may be endangered due to the possible entanglement in a net of issues. One of the greatest problems refers to organizational and functional aspects, which directly or indirectly affect the size and efficiency of any security structure that has been modified. The organizing process of the police and the army leads towards creation of such a structure that defines the task division, cooperation methods among various sectors and the departments, the utilization of the resources etc. This conceptualization of any specific approach towards the internal organizational set-up of the police and the military focuses on the following: the individuals that execute certain tasks within the structure; relations in the formal information system, responsibility for carrying out the decisions, hierarchical subordination, activity planning that would enable the necessary coordination and cooperation etc. The subjects that work within any organizational structure are in constant mutual interaction. The mutual relations among the employees in the organization itself, who take certain posts and have designated missions, are more or less formalized and are regulated in legal acts (Bakreski 2010).

In general, the organizational structure of the police and the army is composed of a sum of relations established among different posts and different persons that hold the posts. The organizational structures of the police and the military have horizontal and vertical dimensions. The vertical dimension is displayed through the levels of authority, while the horizontal dimension refers to departmentalization. Seen through the vertical dimension, the levels of authority are sorted in a hierarchical form (from the top to the bottom; i.e. from the minister who is on the top of the pyramid down to the level of immediate executors). The relations emanate from the delegated authority from one level to another, while between the levels there is a continuous communication with which the authority is passed between the levels.

This is a standard approach that helps understand the relations of authority in the police and the army. Yet, in order to fully understand the problems linked with the police and the army organization, it is necessary to have a proper knowledge about the levels and the methods in which they are created.

The next problem is connected with the legal vacuum that exists with regard to the coordination between various institutions, services and bodies that deal with internal security and the security assessments. Clearly, one of the basic weaknesses in this respect 
is the lack of consistent and regular channels of communication and cooperation of the key actors in the security sector (Vankovska 2003).

In order for the security sector to efficiently execute its missions, there should be a certain degree of coordination of the activities. The coordination has a great significance for the endurance and successful functioning of every institution, respectively, the country as a whole. The success of the coordinated activities depends on the capabilities, skills, and experiences of the leading structures; on the type of the activity and complexity of the tasks that are supposed to be executed; on cooperation between the subjects; on the timely manner in which the coordination is performed etc. But, regardless its success or failure, the coordination remains the key segment and a basic need in all of the institutions, bodies and organizations (Bakreski 2002, p. 9).

The coordination of the security sector in 2001, during the military crisis, was one of the biggest challenges and hardships for the security system of the Republic of Macedonia. We were witnessing a substantially weak coordination, especially between the Ministry of Interior and the Ministry of Defense'.

Still, it has to be emphasized that regardless of the steps undertaken during the past years $\left(2006,2007,2012\right.$ and 2013) ${ }^{2}$, the coordination between the police and the army of the Republic of Macedonia remains a great challenge. So, regarding the coordination between the police and the army there are still many difficulties, but it hasn't been forgotten that the problems tied with the coordination are from the kind that are treated as

${ }^{1}$ The following example could be indicated as mal coordination: in Arachinovo there was a mal placement and the weak coordination between the police and the army on the ground, which caused imperilment of the positions both for the Army and for the Police. The plans of the Army were unacceptable for the Police, and vice- versa. The security structures undertook offensive for eliminating the NLA members in the village, but the offensive was disrupted because of the controversial pressure of the international community. There were claims that among the members of the PLA in Arachinovo there were western military experts and mercenaries. (See Kostova, J., Unfinished Peace, Bata Press, Sofija - Bogdanci, 2003).

${ }^{2}$ In 2006 a Manual for Operative and Other Procedures of the Army of the Republic of Macedonia was brought as a support of the police in case of crisis, and in 2007 the cooperation was manifested through the two joint exercises "Link -07" and "Vodno-07". In 2012 a Memorandum for Cooperation was signed between those two institutions, while in 2013 the Ministry of Interior created a Manual for Operative and Other Procedures of the Police in Terms of Hostility as a support for the Army of the Republic of Macedonia. 
permanently opened issues which demand new answers. We continuously come back on the questions that concern coordination, because it has a great significance for the uninterrupted functioning and the survival of the state and it is worth to durably engage for it. In this direction, and in order to improve the mutual cooperation and coordination between the Ministry of interior and the Ministry of defense for the efficient conduct of their competencies an additional synchronization and precision is of their joint activities is needed. This could be made with faster steps, especially after the signing of the Memorandum for cooperation between the two ministries in 2012. In the next phase remains to precise the cooperation with concrete protocols in all the segments where there is a need for a common, synchronized and coordinated deportment for the solution of complex security tasks (Bakreski 2013).

The next problem which contributes for rendering more difficult reforms is the weak communication between the civil sector and the security sector. For a successful reform conduct, a precondition is establishing an efficient communication between the civilian and the security sector, which could be strengthen the trust between those two components and positively reflect on the dynamics of the reforms. The immediate communication and cooperation of these two sectors contributes for the intensification of the efforts for finding solutions which will be in the function of the security sector. Basically, the security sector reform in the civil and in the military component poses a real challenge and a high political and strategic priority in many countries. Hence, one of the fundamental preconditions for a successful implementation of the reforms is establishing an effective communication between the civil and the military sector, which could increase the trust between those two structures and could positively reflect on the range, the dynamics and the quality of the reforms.

A big problem is the issue on the decrease of number of employees as sort of a need for reduction of the staff in parallel with the reduction of amortized and outdated equipment. The solution is nominally seen through "superseding" of certain numbers expressed through the numeral ratio of the employees and the projected organizational structure, but yet those activities should accomplish the necessary balance through finding a reasonable level of capacities which will simultaneously be a sufficient response for the risks and threats for peace and security.

The following question which deserves attention is the issue of the intelligence community reforms. Today's intelligence system of the Republic of Macedonia is a result of the process of reorganization, adaptation and development of a security-intelligence 
services designated and organized for conducting a broad spectrum of tasks with a security character.

It has to be previously emphasized that similarly as other post-socialist states, also the Republic of Macedonia, after the socialist collapse began with great social reforms, which had the purpose to establish democratic standards in the country. The most essential part of those reforms was the transformation of the intelligence-security system, with a sole purpose for its role to be demystified and to be put under civilian control, and its activities to be in accordance with the law. Under the influence of the past, the reform in the intelligence- security system was far more sensitive than in the other social segments, but also brought certain dilemmas whether the best solutions have been made, which would enable for the intelligence-security system to response the needs of the politics and the country.

Thus a sensitive issue is also the question for the coordination of the intelligence community in the Republic of Macedonia. At this moment, there is a dispersion of intelligence activity and it is organized in numerous institutions, respectively, in various departments, without joint coordination. There is a need for a functional dependence and connection between the Intelligence agency, the Sector - Department for military security and intelligence in the Ministry of Defense and the Direction for security and counter intelligence in the Ministry of Interior.

That would mean that the intelligence system is subjected to transformation beside the defense reforms, which are conducted in continuity and the achieving police reforms. Yet, without the real designation of the intelligence services, there is no efficiency in the functioning of the national security system (Bakreski 2005).

In order to excel the coordination problem in the intelligence community, two decisions were made in September 2003: one by the President of the Republic of Macedonia and the second decision by the Prime Minister. These decisions were in the direction of providing the necessary coordination of all the intelligence structures, especially during the conduct of complex security tasks for the harmonization of the activities.

It could be said that these decisions were a good base for establishing a concrete cooperation and in a certain manner the desired coordination started to be achieved in the intelligence segment of the country. So, gradually the functional connection of the intelligence community was provided through a permanent functional connection which was going on uninterrupted during the process of communication and cooperation, which helped 
providing flow of information and enabled all the tasks and roles to be availed smoothly (Bakreski 2013).

The experience shows that this approach did not justify the expectations. The overall coordination of the intelligence community is impossible partially because of the unfinished and non brought legislative solutions in this area.

\section{Conclusion}

Although certain results have been achieved, the security sector reform in the Republic of Macedonia remains a relatively new challenge that opens space for further improvements and perfection. The reforms should be dovetail in a broader social framework, but at the same time, the political context should not be forgotten. It is considered that the security sector is still connected with the bad habits of party control on certain segments in the security sector. It creates problems in the adaptation which influences society and reflects on different ways. For the Republic of Macedonia, which has no long democratic tradition, the main purpose of the reforms is forming strong security structures, greater coordination of the security community and strengthening the democratic control of the security sector.

A key precondition for successful reforms in the security sector is that the political leadership, the security institutions, as well as the experts from the ministries connected to security, along with other relevant bodies which enforce security should understand and accept the security sector reform concept as something indispensable. They should implement it and enforce it in their training, in their functions and activities, and pass further the concept to the lower levels of hierarchy. That would presuppose incorporating the principles of democratic control over the security institutions, rule of law at every management level, respect for the human rights of the employees and the citizens. In addition, it should be noted that the reforms are not solely intended for the key departments for defense and security, but also for the numerous other organs and bodies which are part of the security sector of the state. It would enable a comprehensive transformation of the security sector which should make it accountable and prepared to response adequately to all the security challenges.

The security sector reform remains a politically sensitive issue in the Republic of Macedonia. In order to be successfully conducted, a complete engagement of all of the subjects in the country is necessary. That would mean that there are no conditions for 
reforms without enabling a transparent reform plan, which will be a reflection of the overall efforts of the politicians, the administration, the civil society and the business community. Hence, there is no dilemma that the Macedonian security sector should be transformed, in order to be capable to respond to the security threats in the country. In that context, changes in all of the segments are needed in order for the shifts in the structure to be a reflection of the overall efforts for change in the direction of enabling the preconditions for creation an efficient security sector. That would mean a complete utilization of the human resources, creating an integrated security system, respectively, institutions prepared for maintaining the internal security.

\section{Bibliography}

1. Bakreski 0., Koordinacija na bezbednosnata zaednica na Republika Makedonija, Filzofski fakultet, Skopje, 2005.

2. Bakreski 0., Osnovi na bezbednosniot menagment, Filozofski fakultet, Skopje, 2011.

3. Bakreski 0., Kontrola na bezbednosniot sektor, Filzoofski fakultet, Skopje, 2012.

4. Beeson, M., Bellamy, A.: Securing South-East Asia. The Politics of Security Sector Reform. Routledge, Taylor \& Francis Group. 2008.

5. Born Hans and Albrecht Schnabel. Security Sector Reform in Challenging Environments. DCAF

6. Bruden, A. and Heiner Hänggi (eds.), Reform and Reconstruction of the Security Sector, Lit Verlag Münster, 2004

7. Christensen, T., Lægreid, P.: The Whole-of Government Approach to Public Sector Reform. PAR, Volume 67, Issue 6. 2007.

8. Defence and Security Sector Governance and Reform in South East Europe: Insights and Perspectives, Volume II Macedonia, Moldova, Romania, Geneva Centre for the Democratic Control of Armed Forces, Genneva/ Belgrade, 2003

9. Ditrich F., Nonmilitary Aspects of Security: A Systems Approach, UNDIR, 1993

10. Ekengren, M., Simons, G.: The Politics of Security Sector Reform. Ashgate Publishing Limited, 2011

11. Edmunds T., Security sector reform in transforming societies: Croatia, Serbia and Montenegro, Manchester Unuiversity Press, Manchester, 2007 
12. Fluri Philipp and Shalamanov Velizar (eds.), Security Sector Reform: Does It Work? Problems of Civil-Military and Inter-Agency Cooperation in the Security Sector, Geneva Centre for the Democratic Control of Armed Forces and George C. Marshall, Sofia, 2003

13. Fluri, P. H., Gustenau, E. G., Pantev, I. E.: The Evolution of Civil Military Relations in South-East Europe. Continuing Democratic Reform and Adapting to the Needs of Fighting Terrorism. Physica - Verlag Heidelberg, 2005.

14. Gyarmati Istvan and Scott Vesel (eds.), Security Sector Governance in the Western Balkans 2004, Nomos Verlagsgesellschaft, Baden-Baden, 2004

15. Hunggi, H.: Conceptualizing Security Sector Reform and Reconstruction. Pdf.

16. Huhn, J. S.: Rebuilding the Security Sector in Post-Conflict Societies: Perceptions from Urban Liberia and Sierra Leone. DCAF, Lit- Verlag Dr. W. Hopf, Berlin, 2010.

17. Jackson, P.: SSR and Post-conflict reconstruction: The Armed Wing of State Building. Pdf.

18. Mühlmann, T.: Police Restructuring in Bosnia and Herzegovina: Problems of Internationally Led Security Sector Reform. Journal of Intervention and State Building. Volume 2, Issue 1. 2008.

19. Post Cold War Defense Reform, Library of Congress Cataloging-in-Publication Data by Brassey's, Inc. 2002

20. Trapans Jan and Fluri Philipp (eds.) Defence and Security Sector Governance and Reform in South East Europe: Insights and Perspectives, Volume I, Albania, Bulgaria, Croatia, , Geneva Centre for the Democratic Control of Armed Forces, Genneva/Belgrade, 2003

21. Wróbel, J.: "Security Sector Reform and Transparency Building. Needs and Options for Ukraine and Moldova". HARMONIE PAPER 17, 2004. PDF. 